\title{
Nigeria: In Search of Sustainable Peace in the Niger Delta through the Amnesty Programme
}

\author{
Olubayo Oluduro ${ }^{1} \&$ Olubisi F. Oluduro ${ }^{1}$ \\ ${ }^{1}$ Department of Public Law, University of Ghent, Belgium \\ Correspondence: Olubayo Oluduro, Department of Public Law, University of Ghent, Universiteitstraat 4, 9000, \\ Belgium. E-mail: olubayooluduro@yahoo.com
}

Received: April 27, 2012 Accepted: May 28, 2012 Online Published: June 15, 2012

doi:10.5539/jsd.v5n7p48

URL: http://dx.doi.org/10.5539/jsd.v5n7p48

\begin{abstract}
Environmental pollution by way of oil spillage and gas flaring are the lots and bane of the Niger Delta region of Nigeria, where the country's oil exploration activities are carried on by the oil multinational companies (MNCs). The cries of the people as well as several non-governmental organizations for attention to the area were not only spurned, but were at intervals rebuffed with crackdown and repression from successive administrations in the country, with the strong connivance of the oil MNCs. The situation reached a crescendo, when the people of this region took to self-help by bombing, kidnapping and abducting the expatriates and other categories of personnel of the oil MNCs in exchange for monetary ransom. The government not able to bear the embarrassment and the drop in daily oil production, coupled with the substantial loss of revenues devised the amnesty programme in 2009 as solution to the quagmire. The paper is aimed at examining the circumstances causing the crisis situation in the area, and the attendant consequences to the people of the areas and to the global community. It will attempt a critical analysis of the amnesty programme of the Federal government as a last resort and its impact at ensuring durable peace and sustainable development in the region. It discusses some of the challenges to amnesty programme and concludes with potential policy recommendations.
\end{abstract}

Keywords: amnesty, Niger Delta, oil exploration, pollution, multinational corporations

\section{Introduction}

With the commencement of oil exploration in commercial quantities in Oloibiri in the Niger Delta in 1956 came great excitement and tall hopes for rapid development and accelerated civilization. But little was known of the pains associated with the exploration of oil such as spillage, deforestation, noise pollution and sundry other ecological effects. These adverse effects have been more of the lots of the people of the Niger Delta area since then until a time when it dawned on them that the government was not willing to yield to their demands for adequate attention to their polluted and depreciating environment. The persistent neglect was to result in unrests by the people of the area, which eventually almost got out of hand. Long years of neglect and conflict have promoted, especially among youths a feeling of a bleak future, and thus see conflict as a stratagem to escape deprivation (Niger Delta Human Development Report, 2006). This resulted in the government cracking down with the strong support, active influence and connivance of the oil multinational corporations (MNCs), which reached a crescendo with extra-judicial hanging of the Prize nominee Ken Saro-Wiwa and eight other kinsmen in November 1995, by the infamous government of the maximum ruler- General Sani Abacha (Oshionebo, 2009). The resultant effect was the outbreak of armed conflicts in the area, abduction and kidnapping of oil workers, especially the expatriates.

Exploration and extraction of natural resources have been known to always affect and alter the geophysical environment of the areas where they are carried on. The environmental impact of oil exploitation in the Niger Delta region of Nigeria has contributed in no small measure to the destruction of the fragile ecosystem, thus making the region 'one of the world's most severely petroleum impacted ecosystems and one of the 5 most petroleum-polluted environments in the world' (Niger Delta Natural Resource Damage Assessment and Restoration Project, 2006). In Canada, there was the mass protest in September 2011, in Ottawa by members of a concerned community where the extraction of tar sands was said to have amounted to erosion of human rights, catastrophic climate change, poisoned air and water and complete stripping of Canada's morality in the international community (Tar Sands Action, 2011). It was described by the Council of Canadians as 'one of the 
largest acts of civil disobedience on the climate issue that Canada has ever seen' (Indian Country Today Media Network [ICTMN], 2011). To neglect utterly environmental and human rights issues of the people in exploration of resources is known to bring about crises and catastrophes as witnessed in the Niger Delta and Canada, among other notable spots in the world. Indeed, Nigeria presents a perfect example of a curse that natural resource can bring (Mähler, 2010; Collier \& Hoeffler, 2001). Although, oil exploitation in commercial quantity began in 1958 , two years after it was discovered in Oloibiri (now in Bayelsa State), with increase in revenue generation to the federal, State and local governments, the poverty level in Nigeria however continues to increase. Almost 90 per cent of the local inhabitants of the Niger Delta fall below the poverty line of $\$ 1$ dollar per day as they depended on the aquatic resources for their livelihoods (Watts, 2008). A situation typified as a 'resource curse,' the 'devil's excreta,' or the source of the 'Dutch Disease' (HRW, 2007). Hence, rather than the oil bringing blessings and fortune for Nigerians, its proceeds have resulted in impoverishing the masses and creating violent conflicts in the Niger Delta region. However, several developmental initiatives have been taken by the Nigerian government to enhance the socio-economic development of the region, such as the establishment of development boards, provision of basic infrastructural facilities, among others. While some of these initiatives are laudable and need to be strengthened (Ukiwo, 2010), they have however failed to achieve endurable peace in the region because they failed to address the root causes of the Niger Delta conflicts. The search for a permanent and sustainable peace in the Niger Delta region has led to the proclamation of an amnesty to the Niger Delta militants in June 2009 by President Umaru Yar'Adua, in exchange for disarmament, rehabilitation and reintegration, with the belief that this is going to bring a lasting peace to the region.

The paper attempts a critical analysis of the amnesty programme of the Federal government as a last resort and its impact at ensuring durable peace and sustainable development in the region. It engages this discourse in five parts including this brief introduction. The second part provides an overview of the Niger Delta conflict to determine the role it plays in the enthronement of militancy in the region. While the third section examines the amnesty initiatives of the federal government and its processes, the fourth section discusses the various challenges facing the implementation of the amnesty programme. The fifth section concludes by making recommendations aimed at resolving the conflicts and ensuring an enduring peace in the Niger Delta region.

\section{An Overview of the Niger Delta Conflict}

The struggles over oil, particularly the quest to correct the perceived injustices embedded in the separation of those that profit from the oil production and commoditization (MNCs and the Nigerian ruling elites), from the others (dispossessed local inhabitants) whose land and waters the oil is extracted, has led to the violent agitation in the Niger Delta region $(\mathrm{Obi}, 2010)$. The publicity and tempo of the agitation for environmental justice increased in the region with the formation of the Movement for the Survival of Ogoni People (MOSOP) in August, 1990; the November, 1995 hanging of Saro-Wiwa and eight Ogoni compatriots; the punitive expedition against the inhabitants of Odi in February, 2000; the formation of the Ijaw Youth Council in December 11, 1998 and the famous Kaiama Declaration on 11 December 1998. Others groups that were formed during these periods include the Movement for the Survival of Ijaw Ethnic Nationality (MOSIEN), Community Rights Initiative (CORI), Niger Delta Women for Justice (NDWJ), Chiccoco Movement, Ijaw National Congress and Egbema National Congress. These groups have continued to criticize the government and the oil MNCs for the environmental damage caused due to the oil exploration activities by the MNCs. This situation in the Niger Delta is well captured by Ken Saro-Wiwa in his presentation on why he championed Ogoni cause, in this way: 'I looked at Ogoni [Niger Delta] and found that the entire place was now a wasteland; and that we are victims of an ecological war, an ecological war that is very serious and unconventional. It is unconventional because no bones are broken, no one is maimed. People are not alarmed because they can't see what is happening. But human beings are at risk, plants and animals are at risk. The air and water are poisoned. Finally, the land itself dies. Oil has brought nothing but disaster to our people [Niger Delta] (Saro-Wiwa, 1998). What can be inferred from this is that the failure of the Nigerian government to address the development needs of the region and to address the environmental damage caused by the oil exploration activities of the MNCs created a feeling of injustice in the Niger Delta people and led to the conflicts and insecurity in the Niger Delta region. It then becomes clear that the struggle is for an end to injustice, discrimination, exclusion, oppression, domination and exploitation, systematic destruction of the ecosystem, corporate and environmental bad governance, a call for equitable federation of Nigeria's economic policy.

It is sad to note that since around 2005, the pattern of unarmed peaceful protests and demonstrations used by these groups against the unwholesome activities of the MNCs operating in the Niger Delta region has been shifted to a violent one by the armed militant groups, like the Movement for the Emancipation of the Niger Delta (MEND), Egbesu Boys, Niger Delta People's Volunteer Force (NDPVF), and others to the extent that the whole region had become highly militarized. The rise of groups like the MEND is said to be traceable to the lack of 
space for peaceful opposition movements and the failure of the government and the MNCs in ensuring that the Niger Delta people enjoy the benefits of oil production (Bassey, 2008).

The response of the government to the claims of the oil producing areas has been classified by Suberu (Suberu, 1996) (Note 1) into three forms: redistributive, reorganizational and regulatory state responses. According to Suberu, 'redistributive policies are state decisions that consciously dispense valued resources to one group at the expense of other claimants to state resources. Reorganizational policies refer to state efforts to restructure or reconfigure political or administrative institutions and relationships in order to accommodate group demands or strengthen the efficacy of centralized state power. Regulatory policies entail the mandatory imposition of sanctions or restrictions on individuals or groups that are perceived to pose a threat to state cohesion and order.' These included the creation of separate federal States in the Niger Delta, viz Akwa Ibom, Delta, and Bayelsa States in 1987, 1991 and 1996, respectively (reorganizational policies) (Omotola, 2007), the increase in the percentage of revenue allocation based on derivation from 1.5\% to 3\% in 1992 and 13\% in 1999 (Osaghae, 2008), the installation of His Excellency, Dr. Goodluck Jonathan, the former Governor of Bayelsa State, an Ijaw man, as Vice-President of Nigeria in 2007 under the People's Democratic Party (PDP) (now President of the Federal Republic of Nigeria in May 2010 following the death of President Umaru Yar'Adua on the $5^{\text {th }}$ of May, 2010) and his subsequent election in May 2011 for another four year term and the establishment of development agencies, such as NDDB, OMPADEC, NDDC, etc (redistributive policies). The repressive response of the State include the execution of Ken Saro-Wiwa and eight other Ogoni leaders in 1995 by the Military government of late Gen. Sani Abacha, the Umuechem massacre of 1990 (African Concord, 1990; Suberu, 1996) (Note 2), the Ogoni genocide (The News May, 1993; Suberu, 1996) (Note 3), the Odi Massacre of 1999 (Aghalino, 2009) (Note 4), the Odioma killings in 2005 (Aghalino, 2009) (Note 5) and Gbaramatu Massacre of 2009 (Adebayo, 2009) (Note 6) among several communities in the Niger Delta. The protesters in these communities not only have their properties destroyed but were also killed, maimed, raped, displaced or forced into exile (Oshionebo, 2009; Ekine, 2008). The local inhabitants see these as a form of repression to keep them (minorities) from voicing even the most moderate claims. These responses from the government and the oil MNCs elicited violence from the Niger Delta people in the form of kidnapping, hostage taking, bunkering and oil theft, pipeline vandalisation, bombings, oil-facility sabotage, destructions of properties and even killings of people in pursuance of the struggle.

\section{Amnesty Initiatives in the Niger Delta}

Following his inauguration in May 2007, President Umaru Yar'Adua promised to address the Niger Delta conflicts, and so recognised it in his seven-point agenda. In fulfilment of his promise, the late President Yar'Adua in line with the suggestion of the Niger Delta elders (Obi \& Rustad, 2011) (Note 7) inaugurated the Technical Committee on the Niger Delta. This 45-member Committee was inaugurated on 8th September, 2008 to collate and review all past reports on Niger Delta, appraise their recommendations and make other proposals that will help the Federal Government to achieve sustainable development, peace, human and environmental security in the Niger Delta Region. The Committee under the Chairmanship of Ledum Mitee, MOSOP President had submitted its report (Report of the Technical Committee on the Niger Delta, 2008) to the Federal Government since 1st of December 2008 (Mitee, 2009). The Committee's recommendations include appointing a mediator to facilitate discussions between government and militants; granting of amnesty to some militant leaders; launching a disarmament, demobilization and rehabilitation campaign, and increase in the percentage of oil revenue to the Delta to 25 percent from the current 13 percent; establishing regulations that compel oil companies to have insurance bonds; making the enforcement of critical environmental laws a national priority; exposing fraudulent environmental cleanups of oil spills and prosecuting operators, ending gas flaring by 31st December 2008 as previously ordered by the Federal Government (Report of the Technical Committee on the Niger Delta, 2008).

In line with the determination of the government to address the Niger Delta problem, the government partly yielded to the report of the Technical Committee by setting up a Presidential Panel on Amnesty and Disarmament of Militants in the Niger Delta on the 5th of May, 2009 to implement the recommendation concerning the granting of amnesty to Niger Delta militants. In its recommendations, this Panel set out the terms, procedures and processes of the grant of an amnesty to the Niger Delta militants. Accepting the recommendations, President Umaru Yar'Adua pursuant to section 175 of the 1999 Constitution of Nigeria granted 'amnesty and unconditional pardon to all persons who have directly or indirectly participated in the commission of offences associated with militant activities in the Niger Delta' (Vanguard, 2009). Under Section 175, the President may, after consultation with the Council of State (a) grant any person concerned with or convicted of any offence created by an Act of the National Assembly a pardon, either free or subject to lawful conditions; (b) grant to any person a respite, either for an indefinite or for a specified period, of the execution of any punishment imposed on that person for such an offence; (c) substitute a less severe form of punishment for any punishment imposed on that person for such an offence; or 
(d) remit the whole, or any part of any punishment imposed on that person for such an offence, or of any penalty, or forfeiture otherwise due to the State on account of such an offence.

The amnesty which was unveiled on 25th June, 2009 was scheduled to run between 6th August to 4th October, 2009 , that is, a 60 day period; and was 'predicated on the willingness and readiness of the militants to give up all illegal arms in their possession, completely renounce militancy in all its ramifications unconditionally, and depose to an undertaking to this effect' (Federal Government of Nigeria, Niger Delta Amnesty Programme). During the declaration, the President acknowledged the fact that the challenges in the Niger Delta arose as a result of the inadequacies of the previous attempts at meeting the yearnings of the people of the region, which thus led to the restiveness witnessed in the Niger Delta. The high incidence of violence in the Delta led to the amnesty initiatives. As a matter of fact, in the first nine months of the year 2008, about 1,000 people lost their lives, 300 were taken hostage and the government lost $\$ 23.7$ billion to attacks, oil bunkering and sabotage (Report of the Technical Committee on the Niger Delta, 2008). Apart from the inability of Nigerian government to meet up with its OPEC quota and other negative economic effects, the oil MNCs on their part reportedly lost billions of dollars to the conflicts. For instance, between 2003 and 2007, Shell Petroleum Development Company (SPDC) estimated that it lost US $\$ 10.6$ billion, with a total loss of not less than US $\$ 21.5$ billion by the oil MNCs as a whole since 2003 (Nwozor, 2010).

It can be seen that a major drive for the use of amnesty in the management of oil-related conflicts in Nigeria is the belief that it is only through peace that sustainable development can be guaranteed in the Niger Delta.

\subsection{Niger Delta Militants: Freedom Fighters or Criminals?}

Several analysts and scholars have used different names, such as rebels, insurgents, terrorists, revolutionaries, criminals, cults and gangs, freedom fighters, to describe those behind the Niger Delta crisis. Edwin Clark, an Ijaw leader, prefers to refer to them as 'freedom fighters' (Fabiyi \& Olokor, 2010), as they are seen as a new generation of ethnic men engaged 'in a struggle for freedom and justice, not for themselves, but for their people' (Osaghae, 2011). This is with a view to distinguishing genuine militants believed to be fighting the just cause of the Niger Delta from 'criminal elements' motivated by greed (Ukiwo, 2011) and pecuniary gain and masquerading as militants. According to Osaghae et al. (2011):

'In the Niger delta, the term 'militants' refers to gunmen who make political demands, including the release of imprisoned leaders, cash reparations for communities, change of electoral candidates and a greater share of oil revenues, among other issues. These political demands distinguish them, albeit tenuously, from criminals who simply kidnap people for money. Militants are also distinct from disaffected communities, whose people may perform kidnappings or attacks in the hopes of getting a clinic, school or cash, but have no overall political aims' (Osaghae et al., 2011).

Two broad segments of youth militia are discernible, viz: the genuine militias and the criminalized militias, with the latter comprising small cults and gangs. As noted by Ako (Ako, 2011; Ikelegbe, 2011), though motivation for recourse to violence determines the classification of a group as militant or cult, it is not easy to distinguish between the two as they often interact in somewhat symbiotic relationships. Furthermore, while cults and gangs are primarily motivated by the financial benefits they derive from their activities such as illegal oil bunkering, political thuggery, drug peddling, kidnapping for ransom, armed robbery, piracy, etc, militants also engage in these activities; although with underlying 'identified causes' (Ako, 2011). The broad nature of the alliance of insurgent militias and the porous boundaries between them and other groups give room for infiltration by the various criminal elements who now use the name of militias to perpetrate various acts most of which smear the image of the struggle (Ikelegbe, 2011).

\subsection{The Amnesty Programme and DDR}

Disarmament, Demobilization and Reintegration (DDR) is one of the most important ways of resolving conflicts and managing post-conflict situation in the world to ensure peace. This has been variously used by the United Nations and other similar bodies as an instrument for achieving sustainable peace (Ibaba, 2011). This was adopted by the Nigerian government in its amnesty programme in the Niger Delta. There are three phases to the amnesty programme, viz., the disarmament and demobilisation of militants; the rehabilitation and integration of ex-militants and the final stage is the post-amnesty package of huge infrastructural development. The disarmed militants were taken to designated collection points and camps in six Niger Delta states, with a promise of a payment of N65, 000 [approximately \$407 USD] monthly, the payment of rent and offering of vocational training (Oluwaniyi, 2011). During the first phase which has already been implemented, several militants turned in several arms and ammunitions (Kuku, 2011). Indeed, it was recorded that about 26, 358 ex-militants accepted the amnesty offer (first phase- 20,192 militants representing those that accepted the offer on or before 4 October 
2009, while the second phase of the amnesty programme that occurred in November 2010 comprises 6,166 militants representing those that accepted the offer post 4 October 2009). This appeared to have reduced the incidence of conflict and the accumulation and influx of arms by militants in the region. Some rehabilitation centers were provided for the second stage which was tailored to meet training needs of the ex-militants. The trainings were to be done in batches as the centers could only accommodate few numbers of registered ex-militants. It is expected that each batch would spend four weeks in the rehabilitation programme, which involves reorientation, counseling and moral/spiritual regeneration of the ex-militants (Akinwale, 2010). A survey of the career aspiration of the ex-militants reveals a great preference for about ten (10) sectors ranging from Oil/Gas, Maritime Services, Fabrication and Welding Technology, Exploration and Production and Processing Engineering, which duration of training ranges is projected to last between 3-18 months (Akinwale, 2010). Those desirous of going back to school for further education are also given the opportunity under this programme.

\section{Prospects and Challenges Facing the Implementation of the Amnesty Programme in Nigeria}

Reports from the government indicate that following the relative peace ushered in by the cease-fire as a result of the amnesty declaration, the country's oil output had risen to 2.3 million barrels a day from 800,000 barrels per day (in the 2006-2008 period) as a result of the improvement in security in the oil region (Igwe, 2010). An increment of 1.5 million barrels per day indicates 120.45 million dollars of revenue to national coffers every day (Igwe, 2010). Some companies also took the opportunity to repair some of their damaged oil facilities.

Without doubt, the amnesty programme is expected to improve the human capital development of the country which is presently low. Nigeria's Human Development Index (HDI) value (comprising three basic dimensions of human development: a long and healthy life, access to knowledge and a decent standard of living) for 2011 stands at 0.459 , positioning the country at 156 out of 187 countries and territories (UNDP 2011). If well implemented, the amnesty programme in Nigeria could serve to negate the 'resource curse' theory that resource-rich economies such as Nigeria, Congo, Angola, etc. are more prone to mismanagement, underdevelopment and violence. Examples of UK and Norway, both major oil exporting countries, reveal that resource curse is avoidable with functioning institutions and good governance in place.

Notwithstanding the achievements of the programme, reports from the panel set up in January 2010 to review the rehabilitation aspect of the DDR revealed some inadequacies thus leading to calls by elders in the Niger Delta region for the dissolution of the Presidential Amnesty Committee. Some of these include the fact that about 80 percent of the budget had gone on payments of consultants and contractors, with 20 per cent committed on rehabilitation of the ex-militants; the over bloating of the numbers of registered ex-militants; the continued detention of several militants; some of the training centers falling short of acceptable standards and operating with inadequate facilities (Obi \& Rustad, 2011). Commenting on the flaws of the amnesty programme, Nwajiaku-Dahou (2010) stated that:

'Allowances unpaid or not paid regularly, huge disparities between payments made to foot soldiers and former militant commanders, limited access to rehabilitation training and allowances for those who surrendered weapons after the deadline, inappropriate training provision, limited employment prospects, the absence of a broader political settlement involving the broader Niger Delta population that has born the costs of conflict, and the politically motivated staffing of bodies responsible for implementing and coordinating the amnesty program, are among the numerous flaws of the Amnesty' (Nwajiaku-Dahou, 2010).

The Federal Government on 2 December 2009 scrapped the Presidential Committee on Disarmament and Amnesty for Militants in the Niger Delta, and in its place are five new committees put in place to handle the post-amnesty programmes and fast-track development challenges in the region (Adebayo, 2009). These were the Presidential Monitoring Committee on Amnesty; the Infrastructural Committee; the Disarmament and Reintegration Committee; the Oil and Gas Assets Protection Committee; and the Environmental Remediation Committee.

One of the major challenges of the amnesty package is in the area of poor implementation. The amnesty programme was not implemented as recommended in the report of the Niger Delta Technical Committee. Rather than engage in open negotiations or a formal peace agreement with the militants, the consultations were at the highest levels of federal government, involving Niger Delta elites/elders and top government officials of Niger Delta origin negotiating with the militant commanders (Obi \& Rustad, 2011). This top down non-inclusive approach, through the militant commanders who are only interested in what comes into their pockets, or for their own personal aggrandizement is a serious challenge to the amnesty programme as the militants on ground felt cheated and sidelined by the government. It shows that Nigerian government has not really learnt any lesson from the previous failed developmental programmes such as the Niger Delta Development Board (NDDB), 
Niger Delta Basin Development Authority (NDBDA), Oil Mineral Producing Area Development Commission (OMPADEC), which failed to deliver on the basis of top-down approach. For sustainable peace and development in the Niger Delta to be achieved, there is need for the adoption of bottom-up approach through the inclusion of elements of democracy, accountability, equity and active public participation of all stakeholders including the grassroots people (Ako, 2011), militants, youth organizations, women groups and civil society.

Furthermore, the total number of ammunitions/weapons handed in by the militants totaling 1,798 rifles, 1,981 guns of various types, 70 RPGs, 159 pistols, one spear and six cannons (Agbo, 2011) are certainly low when compared with 26, 358 militants that registered for the amnesty programme. The region is still ridden with arms and this is evident in the various attacks that have been carried out by militants even after the disarmament exercise. The disarmament programme needs to be firmed up because as long as many arms are still at large, the region remains very unsafe and at risk of relapsing into violence (Joseph, 2010).

The recent spate of bombings across the region shows that all is not well with the amnesty programme. For instance, MEND set off two car bombs on 15 March, 2010 in Warri, the Delta State capital, where a post amnesty dialogue was being held and this left one person dead and several others injured (Ofehe, 2010). Also important is the 1 October, 2010 car bombing that killed about 12 people and disrupted the Nigeria 50th anniversary celebrations. This led to the current trial of MEND leader, Henry Okah in his base in Johannesburg, South Africa for terrorism on the suspicion of having masterminded the operation; and the trial of his brother, Charles Okah, and three others before the Federal High Court in Abuja on suspicion of involvement (Nwajiaku-Dahou, 2010). Also, on 4 February 2012, the militant group also bombed a trunk pipeline at Brass in Bayelsa State belonging to Italy's Eni SpA, ENI from which it lost 'around 4,000' barrels per day of 'equity production' from the incident (Mamah \& Amaize, 2012). The group further claimed responsibility for the bombing of the Ogbogbabene country home of the Minister for Niger Delta, Elder Godsday Orubebe in Burtutu Local Government Area of Delta State on 28 January 2012 (Mamah \& Amaize, 2012).

Importantly, 'the amnesty is exclusive; it targets only militants without consideration for the victims of militancy and hostage taking in the region' (Akinwale, 2010). Mothers and children who had lost fathers and sons and homes and have been displaced by the conflict were not included in the amnesty package, (Nwajiaku-Dahou, 2010) presumably as a result of their lack of means of violence. The exclusion of grassroots organizations and the alienation of local knowledge from the construction of peace-building process in the Niger Delta raise some questions on the sustainability of the current peace in the region (Obi \& Rustad, 2011). Ibaba (2011) posed the questions thus:

'Does the surrender of arms and renunciation of violence by militias bring the frustration of the entire population to an end? Are the militias the only deprived and aggrieved Niger Delta's? Is the amnesty program and the attention given to the ex-combatants not reinforcing the frustrations of those who did not take up arms against the Nigerian State? My answer to the first two questions is no, but the answer to the third question is in the affirmative. This brings us to the point that violence could recur in the region if the frustrations which support insurgency are not resolved. Resolving these frustrations is therefore a requirement for peace-building in the region' (Ibaba, 2011).

The empowerment policy of the government through the training programme and job opportunities must not be limited to the militants. It must be extended to all the local inhabitants in the region, otherwise, it could send a wrong signal to others who have been excluded from the exercise that crime pays and may serve as a driving force for others to want to take arms for recognition. The amnesty package should not be implemented as a stand-alone act, but must be carried out within a comprehensive peace process, as recommended by the Technical Committee (International Crisis Group, 2009). Thus, government must not only publish the white paper on the recommendations of the Niger Delta Technical Committee, but must also embark on a holistic rather than the current fractured approach to the implementation of the report. This report is believed 'offers an opportunity to reduce the violent conflict significantly and begin long-term regional development in the oil-rich region' and could help to 'save the region from further violence and organized criminality' (International Crisis Group, 2009). Addressing the militants alone while neglecting the deplorable situation, the underdevelopment and poverty, governmental and corporate misgovernance, all of which led to the militancy and later criminality in the region will no doubt spell doom for the amnesty programme. This is because the number of militants presently being reintegrated under the programme constitute only a small percentage of the Niger Delta population, which under the 2006 population figure is 31, 224, 577 million people (Nigerian News census, 2006). Efforts must be taken to remove the Niger Delta people from what Sachs (2005) refers to as poverty trap- a situation in which degraded environment, poor health, poor education, poor infrastructure and poor standard of living reinforce one another (Ogege, 2011). 
In addition, it was revealed that some of the rehabilitation centers and demobilising camps are lacking in even the basic facilities for proper impartation of knowledge and skills. Shortages of bed spaces, beds and other basic facilities in some of the centers made only few militants to be accommodated (Ikelegbe, 2010). Also in compliance with the UN code on DDR, it is expected that in the implementation of the DDR programmes, the ex-militants must be taken away from their natural habitats for transformation and reintegration purposes (Amaize, 2011). For better coordination of the programme, it is suggested that the government agencies involved in the programme need to draw on the experience and professionalism of similar exercises in other countries, including those administered by the United Nations (Obasi, 2009) in countries like Liberia and Sierra Leone. They can also learn from some Nigerians that have helped in formulating and administering similar programmes in other countries. Consequently, there is the urgent need for assistance and cooperation from international communities in the area of technical assistance, capacity building, vocational training and skill acquisition, among others. According to the Amnesty Office, more than 5000 ex-militants have been processed for various vocational, entrepreneurship and educational training in both local and offshore training centres (Federal Government of Nigeria, Niger Delta Amnesty Programme). Aside from countries such as the United States of America, Russia, South Africa, Ghana, Malaysia, India, Sri Lanka, Philippines, Israel, Benin Republic, Poland, Trinidad and Tobago, Cyprus, and the United Arabs Emirate (Dubai) that have already given their support, similar support is still expected from other countries. Within the framework of the EU 2011 Annual Action Plan for Nigeria, the EU approved under the European Development Fund the sum of $€ 478$ million for the funding of about eight projects. Out of this amount, $€ 200$ million was for the EU Niger Delta Support Programme which overall objective is to mitigate the conflict in the Niger Delta by addressing the main causes of unrest and violence- bad governance, provision of training and employment for the youths, improve access to safe, adequate, and sustainable water, sanitation and hygiene (European Commission, 2012). More of these initiatives and support by other developed countries will go a long way in complementing the efforts of the government and MNCs in the development of the region thus bringing about lasting peace.

\section{Conclusion: Recommendations for Resolving Conflicts in Niger Delta}

Beyond amnesty, the underlying economic, social and environmental problems that triggered militancy in the Niger Delta needs to be addressed, as without this, it is doubtful if amnesty alone could bring durable peace to the volatile region. The introduction of the amnesty programme must be effectively backed up by socio-economic development of the entire region. Amnesty alone will only bring a temporary peace to the region. Sooner or later, new and more dangerous groups may emerge in the region if nothing is done to adequately address the root causes of the Niger Delta crisis. Interestingly, following the amnesty proclamation, the President equally announced the relinquishment of ten per cent of the federal government's holdings and interest in the oil and gas resources directly to the oil producing communities of the Niger Delta (Dadem, 2009). This could give the Niger Delta communities an actual financial stake in the revenues derived from oil production, rather than having the money flow primarily to the federal and state governments, and more often, to the pockets of the individuals. If properly utilized, it will go a long way in enhancing the development of the region regarding the development of infrastructure, human capital and the protection of its environment, which could help to curtail the propensity to destroy oil MNCs' facilities or disrupt oil production. However, there is need for machinery to be put in place to ensure transparency and accountability regarding the use of the money at the local level. There is also the challenge concerning the modality to be used in managing the funds, as communities where oil is presently being explored may want to claim monopoly over the monies to the detriment of the communities that oil is presently not being exploited (Dadem, 2009). This may lead to another round of hostilities and conflicts in the region if not properly handled.

Also, the skill acquisition package of the Amnesty programme promises a better future for both the local populations and the companies if well managed. Upon the completion of their training in oil-related skills, the companies should ensure that they are recruited and engaged in the industry through the reservation of some employment quota for the local inhabitants, thus making the local people to identify with the companies operating in the region. As noted by Brill and Haken, the Nigerian economy must be producing jobs so as not to render the jobs training exercise for the ex-militants a mere formality with the result that when eventually the allowances are stopped, they go back to the bush, which some have begun to do (Brill \& Haken, 2011). Explaining the advantage of this, Tom Albanese, Rio Tinto's CEO (Albanese, 2011), in an interview with the Critical Resource cited the investment of the company Sohar smelter, in Oman, where about $90 \%$ of the workers were local hire. He noted that the area was the hotspot in Oman for riots that took place in the Arab spring in 2011. And during the riots, the employees at Sohar went to the plant and stayed there to prevent the rioters from wrecking havoc to the company's facilities, saying 'We will not let the rioters near here; we want to protect our jobs' (Albanese, 2011). Getting the 
local inhabitants to identify with the oil MNCs operating in the region would not only help to provide jobs for the unemployed youths in the region, but will equally help to build the trust and confidence of the people in the oil MNCs, protect the companies' facilities, protect their 'licence to operate' and ultimately bring about an enduring peace in the region.

In addition, the concept of community participation must be deeply entrenched in the region. The development of Nigeria's Akassa programme, which evolved in 1997 out of a partnership between Pro-Natura International (Nigeria) (PNI) and the BP/Statoil Alliance is considered today one of the most successful models of sustainable development in the world (Pro-Natura International, 2011). This participatory development process started in Akassa, a coastal community with nineteen distinct communities in Bayelsa state, which an Environmental Impact Assessment identified most likely to be affected by any oil accidentally spilt from exploration wells in Statoil's offshore blocks (Statoil). The project supports activities such as the abolition of poverty, building local capacity, the environment, the infrastructure and institutional capacity development. Rather than embark on the traditional top-down developmental approach, PNI started by implementing a Participatory Rural Appraisal (PRA) programme through a bottom-up community-driven development approach that enlisted the direct involvement of the local inhabitants in the appraisal of their natural resources (Pro-Natura International, 2011). It involves the active representation and participation of the ordinary people, including women and the youth, in the decision making process towards achieving sustainable development. It allows the communities to be involved in the prioritising, planning, managing, monitoring and evaluating development projects and programmes with the assistance of professional advisers. Akassa model has not only promoted transparency, accountability, infrastructure/micro-projects, poverty alleviation/micro-credit and empowered local ownership and management of development programmes, but has furthered the interests of the community in the protection of oil MNCs facilities in their communities. It was reported that community leaders rounded up and handed to the law enforcements agencies some youths that attacked oil company facility (Ukiwo, 2011) since the community knows that they have a lot to lose by the disruption of the oil operation. As noted by Richard Owens, Nexen's Managing Director in Nigeria, 'self-sustaining enterprises lead to peaceful communities and no disruption to our operations. That's a valuable commodity' (International Petroleum Industry Environmental Conservation Association (IPIECA, 2006). In other words, by engaging in self-sustaining enterprises in the Niger Delta, the oil MNCs are arguably assured of social license to operate by the host community and help reduce their budgets on security which run into hundreds of millions of dollars annually. The Akassa programme has inspired a number of similar programmes in 13 communities across four Southern Nigerian states, including Eastern Obolo, Opobo-Nkoro and Oron, and helping over 1.6 million people (Pro-Natura International, 2011; Ako, 2011). Since decision-making is transparent, community members appreciate why certain development projects were prioritized, and this goes a long way in helping to reduce conflict in a region, like the Niger Delta, where there is so much mistrust and little confidence in decision makers (Statoil). In order to promote sustainable development and peace in the region, the programme can be replicated in the entire Niger Delta region and adapted to the peculiar/cultural circumstances of each community as a vehicle for community development.

Government must also ensure the inclusion of other militant groups that now desired to join in the amnesty programme. Recently, there have been agitations from some of the militants, mostly youths in the region, who failed to avail themselves of the window of opportunity opened to them to accept the amnesty offers- the first phase and second phase- for reason of lack of trust and sincerity in the government over the programme. Having come to realize that the programme has come to stay and gradually yielding some fruits for those that embraced the offer, they are now willing to accept the offer and be included in the programme. While it may be right to say that the window of amnesty cannot be opened for ever, it is submitted that since the primary objective of this programme is to ensure lasting peace in the region, government should be magnanimous enough to accommodate this group. The window of amnesty should be opened to them by ensuring that they are documented and properly integrated into the programme. Sometime, in February 2010, over 400 militants from the communities in Ovia South-West and Ovia North-East Local Government Areas of Edo State, one of the oil producing states, took to the streets of Benin City to protest their exclusion from the amnesty programme (Fabiyi \& Olokor, 2010). Also, between July and early September 2011, rampaging youths of Bayelsa State extraction barricaded the East/West Road (Gbemudu et al., 2011). Idle youths are easy to mobilize and draft into criminality as they know that it can be a means of "'empowerment,' the outcome of the search for new forms of identity and integration, a form of employment and an opportunity for looting and accumulation" (Ikelegbe, 2011; Allen, 1999). The integration of these unemployed youths (idle men and women) into the programme would make them acquire the necessary skills that the programme offers and hence, be useful to themselves and the society, rather than being instruments for violence in the region. The recent protests of some of them of exclusion from the amnesty programme are 
evidence that the programme is on course. However, the gains of amnesty programme will be lost if the youths are allowed to go back to the creeks and rearm.

Also, the success of the amnesty package depends on the collaboration of the state governments, the local governments, the oil MNCs, the Niger Delta Development Commission (NDDC), the Ministry of Niger Delta Affairs, and other intervention agencies. Each of these levels of government, corporations and agencies must strive to contribute their own quota to the success of the programme, particularly in the area of training, creation of employment opportunities and provision of grants for small scale businesses. The investment in training and skill acquisition should not be left for the government alone. The oil MNCs should complement the efforts of the government by ensuring that the local people are given adequate training and brought into the oil industry as local professionals. The amnesty office should also collaborate with the private sector operators as they could also help both in the area of training as well as in job creation and empowerment of the ex-militants. It is gratifying to note that the oil firms, under the Oil and Gas Industry Foundation (OGIF), a Special Purpose Vehicle (SPV) set up to coordinate the support package of the oil and gas industry for the purpose of assisting in the reintegration of the ex-militants of the amnesty programme, had opted to train 3,000 of the about 27,000 ex-militants (Francis, 2012). However, as noted by the Special Adviser to the President on Niger Delta Affairs and Chairman of the Amnesty Programme, Kingsley Kuku, rather than the OGIF train the 3,000 ex-militants it requested as artisans relevant to oil operations, many of them were now being made to undergo training such as tailoring and other fields that were incongruent with what was initially intended (Francis, 2012) or ill-suited to the ambitions of the ex-militants. This is beside the fact that the numbers of ex-militants decided to be assisted by OGIF are rather too small when compared to the numbers of ex-militants that are in the programme. As long as these remain unaddressed, the conflict in the region will definitely continue.

Also important is the fact that even though the Amnesty programme seems to have brought a relative peace to the region, there appears to be little progress being made to end the environmental degradation and human rights abuse that are the lots of inhabitants in the region. Efforts at recovering the damaged ecosystem have been minimal, sporadic and inadequate. The sheer scale of monumental environmental damage to the local fishing and farming, habitat and biodiversity, and the means of livelihood of the people in the region was confirmed by the UNEP Ogoni Environmental Assessment Report (2011) when it called for initial \$1 billion fund to set up an independent fund to clean up pollution in Ogoniland which it believed may take 25-30 years to remediate. The Nigerian government and the oil MNCs should know that the solution to the Niger Delta conflicts lies not only in the Amnesty programme, but also in the cleaning up of the environment and putting an end to incessant gas flaring and oil pollution which directly affect the lives of the people who live in the region. As noted by Governor Bill Richardson, 'The challenges have been growing for more than five decades, it is time to face it squarely...amnesty programme is just the beginning. Implementing the UNEP roadmap will require political will from government, commitment from the company responsible for the spillage and change of attitude from host communities' (Alohan, 2012). In view of the recurrent oil spill in the region and the damaging effect it is causing to the environment and the socio-economic life of the Niger Delta communities and the nation at large, government and the oil MNCs must take seriously the ecological restoration and remediation of the Niger Delta environment. This is one of the root causes of Niger Delta conflicts. Immediate clean-up of the pollution sites of the Niger Delta communities is therefore imperative to avoid the spreading of the oil pollution to places not presently affected thereby worsening the conditions of the people and the environment and exacerbating the conflict in the region.

From the above, it can be contended that the grievances that led to the militancy, and later, criminality in the Niger Delta region borders on ecological damage and inequity in the distribution of economic and other social resources of the Nigerian state. In order to ensure relative peace in the Niger Delta region, all forms of distributive injustice, oppression, adverse effects of oil exploitation, corruption, greed, and all other oil-related grievances, which the local inhabitants believed arose from the denials and abuse of their human rights by the Nigerian state, must be addressed.

It is also important to stress that where the economy is hostile and the people are not getting the much expected democracy dividends, this would provide fertile ground for germination and exacerbation of conflicts. Common conflicts lead to clashes as socio-economic alienation leads to resentment, anger, discontent and frustration against competitors with social miscreants and the growing mass of unemployed in the society taking advantage of minor clashes to cause confusion and loot public and private property (Ukiwo, 2003). Dollard et al. (1939), in what became known as the frustration-aggression hypothesis, contended that 'the occurrence of aggressive behaviour always presupposes the existence of frustration and, contrariwise, that the existence of frustration always leads to some form of aggression' (Draman, 2003). It is in this sense that the frustration-aggression theory and the relative deprivation theory (Note 8) (both of which suggest that individuals become aggressive when 
there are obstacles- perceived and real- to their success in life) (Draman, 2003) becomes important to the Niger Delta conflicts in Nigeria. Democracy means nothing if people do not have access to nourishing food, good health care, good education, access to resources for a good life. Ensuring that avenues are created for ordinary citizens, particularly the Niger Delta people, to earn a decent living must be created by the government in order to reduce the spate of conflicts presently being witnessed in the region. Nigeria should learn from countries like the UK and Norway, both major oil exporting countries, with functioning institutions and good governance in place to achieve a relatively stable socio-economic and political atmosphere that has greatly enhanced their development.

Finally, the civil society and community groups on their part must be vigilant and watchful to report early any signs of conflict or any sudden stockpiles of new arms and ammunitions (Igwe, 2010). The civil society through its oversight role can help to monitor and comment on how the government is handling the amnesty and the Niger Delta developments. It must not only call attention to systemic weaknesses that encourage corruption among the political class (that is, the governors) of the oil rich states, but it must also be proactive in fighting incidence of deep-rooted corruption and patronage in the extractive industry through litigation in the courts. The amnesty should not be seen as a ploy on the part of the government to ensure continued and uninterrupted extraction of oil in the Niger Delta, but one that should help to promote and consolidate peace, jump-start development, raise the standard of living, promote environmental justice and other important peace-related needs.

\section{References}

Adebayo, S. (2009). Niger Delta: We have lost over 2,000 persons- Gbaramatu Kingdom. Punch. Retrieved May 23, 2009, from http://archive.punchng.com/Articl.aspx?theartic=Art20090523643265

Adebayo, S. (2009). N'Delta: FG Scraps amnesty committee, raises five new panels. Punch. Retrieved December 11, 2009, from http://www.punchng.com/Articl.aspx?theartic=Art20091211285762

Agbo, D. (2011). Arms recovered from ex-Niger Delta militants destroyed. Legal Oil. Retrieved May 29, 2011, from http://www.legaloil.com/NewsItem.asp?DocumentIDX=1307016053\&Category=news

Aghalino, S. O. (2009). The Olusegun Obasanjo Administration and the Niger Delta Question 1999-2007. Stud Tribes Tribals, 7(1), 57-66.

Akinwale, A. A. (2010). Amnesty and human capital development agenda for the Niger Delta. Journal of African Studies and Development, 2(8), 201-207.

Ako, R. (2011). The Struggle for Resource Control and Violence in the Niger Delta. In Obi, C., \& Rustad, S. A. (Eds.), Oil and Insurgency in the Niger Delta: Managing the complex politics of petro-violence. London/New York: Zed Books.

Albanese, T. (2011). Q \& A with Rio Tinto CEO: industry needs to 'out' bad actors. Critical Resource, September. Retrieved from http://www.c-resource.com/view_article.php?aid=179

Allen, C. (1999). Warfare, endemic violence and state collapse in Africa. Review of African Political Economy, 81, 367-384. http://dx.doi.org/10.1080/03056249908704399

Alohan, J. (2012). Oil Spill: What Way Forward. Leadership. Retrieved January 25, 2012, from http://leadership.ng/nga/articles/14327/2012/01/25/oil_spill_what_way_forward.html

Amaize, E. (2011). Amnesty: Nigeria, EU to partner on Niger Delta. Vanguard. Retrieved August 13, 2011, from http:/www.vanguardngr.com/2011/08/amnesty-nigeria-eu-to-partner-on-niger-delta/

Bassey, N (2008). The Oil Industry and Human Rights in the Niger Delta. Being his Testimony before the United States Senate Judiciary Subcommittee on Human Rights and the Law. Retrieved September 24, 2008, from http://www.earthrights.org/sites/default/files/documents/Nnimo-testimony-9-24-08.pdf

Brill, K. C., \& Haken, N. (2011). The Future of Nigeria Rests Upon the Niger Delta. The Fund for Peace (FFP) Commentary. Retrieved May 3, 2011, from http://www.fundforpeace.org/global/?q=node/88

Collier, P., \& Hoeffler, A. (2001). Greed and Grievance in Civil War. Washington, DC: World Bank.

Dadem, Y. Y. D. (2009). Current Challenges for Environmental and Economic Justice in the Niger Delta of Nigeria. Kogi State University Bi-Annual Journal of Public Law, 1(1), 219-231.

Draman, R. (2003). Poverty and Conflict in Africa: Explaining a Complex Relationship. Being a Paper prepared for Experts Group Meeting on Africa-Canada Parliamentary Strengthening Program Addis Ababa. Retrieved May 19-23, 2003, from http://www.parlcent.ca/povertyreduction/seminar1_e.pdf 
Ekine, S. (2008). Women's Responses to State Violence in the Niger Delta, 10 Feminist Africa, 67-83.

European Commission. (2012). EU helps Nigeria to consolidate peace in the Niger delta and ensure better governance and improved service delivery' EC12-013EN. Retrieved February 3, 2012, from http://ec.europa.eu/commission_2010-2014/piebalgs/headlines/news/2012/02/20120203_en.htm

Fabiyi, O., \& Olokor, F. (2010). N’Delta elders Behind Militants, Clark Insists. Punch. Retrieved February 3, 2010, from http://archive.punchontheweb.com/Articl.aspx?theartic=Art201002030405750

Federal Government of Nigeria, Niger Delta Amnesty Programme. Yar'Adua's Amnesty Speech. Retrieved from http://www.nigerdeltaamnesty.org/index.php?option=com_content\&view=article\&id=57\&Itemid=84

Federal Government of Nigeria, Niger Delta Amnesty Programme. 20, 192 Participants Successfully Demobilized. Retrieved

from http://www.nigerdeltaamnesty.org/index.php?option=com_content\&view=article\&id=248:20192-participan ts-successfully-demobilized\&catid=39:transformation-camp-update

Francis, N. (2012). Nigeria: Niger Delta - Kuku Raises the Alarm Over Resurgence of Militancy. Retrieved March 10, 2012, from http://allafrica.com/stories/201203110155.html

Gbemudu, E., Emeana, C., \& Adebayo, S. (2011). Amnesty programme: Silent disquiet in Niger Delta. Retrieved October 16, 2011, from http://nationalmirroronline.net/sunday-mirror/big_read/22946.html

Human Rights Watch. (2007). Chop Fine: The Human Rights Impact of Local Government Corruption and Mismanagement in Rivers State, Nigeria, 19(2A).

Ibaba, I. S. (2011). Amnesty and Peace-Building in the Niger Delta: Addressing the Frustration-Aggression Trap. Africana: The Niger Delta (Special Issue), 5(1), 238-271.

Igwe, U. (2010). Is the Niger Delta Amnesty Working? The African Executive. November. Retrieved from http://www.africanexecutive.com/modules/magazine/articles.php?article $=5517$

Ikelegbe, A. (2010). Oil, Resource Conflicts and the Post Conflict Transition in the Niger Delta Region: Beyond the Amnesty. Centre for Population and Environmental Development (CPED) Monograph Series No. 3. Benin City: Ambik Press.

Ikelegbe, A. (2011). Popular and criminal violence as instruments of struggle in the Niger Delta region. In Obi, C. \& Rustad, S. A. (Eds.), Oil and Insurgency in the Niger Delta: Managing the complex politics of petro-violence. London/New York: Zed Books.

Indian Country Today Media Network (ICTMN). (2011). Anti-Oil Sands Protesters Target Ottawa September 26. Retrieved September 24, 2011, from http://indiancountrytodaymedianetwork.com/2011/09/anti-keystone-protesters-target-ottawa-september-26/

International Crisis Group. (2009). Seizing the Moment in the Niger Delta. Africa Briefing No. 60.

International Petroleum Industry Environmental Conservation Association (IPIECA). (2006). Partnerships in the Oil and Gas Industry. London, United Kingdom: An IPIECA Publication.

Joseph, O. (2010). Analysis Nigeria's Delta amnesty at risk of unraveling. Spero News. Retrieved April 23, 2010, from http://www.speroforum.com/a/31526/Analysis--Nigerias-Delta-amnesty-at-risk-of-unravelling

Kuku, K. (2011). Being a Communiqué stating the stand of the Amnesty Office on the Issue of those Niger Delta Youths Clamouring for inclusion in the Amnesty Programme. Retrieved December 8, 2011, from http://www.nigerdeltaamnesty.org/index.php?option=com_content\&view=article\&id=251:press-statement \&catid $=36$ : news\&Itemid $=18$

Mähler, A. (2010). Nigeria: A Prime Example of the Resource Curse? Revisiting the Oil-Violence Link in the Niger Delta, GIGA Research Programme: Violence and Security. Germany: GIGA Working Papers 120.

Mamah E., \& Amaize, E. (2012). Nigeria: MEND Resumes Hostilities- Blows Up Agip Trunk Line in Bayelsa. Vanguard. Retrieved February 6, 2012, from http://allafrica.com/stories/201202060224.html

Mitee, L. (2009). The Niger Delta: A Vision to Nigeria's Development. Being the text of a paper presented at the $5^{\text {th }}$ All Nigerian Editors Conference, Kaduna. Retrieved April 3, 2009, from http://www.nigerianguildofeditors.com/index.php?

Niger Delta Human Development Report. (2006). UNDP Publication. 
Niger Delta Natural Damage Assessment and Restoration Project. (2006). Report. Phase 1- Scoping Report. Federal Ministry of Environment, Abuja Nigeria Conservation Foundation, Lagos, WWF UK, CEESP-IUCN Commission on Environmental, Economic and Social Policy.

Nigerian News census. (2006). Retrieved from http://www.nigeriannews.com/census/census2006.htm

Nwajiaku-Dahou, K. (2010). The Politics of Amnesty in the Delta Niger Challenges Ahead. Paris and Brussels: The Institut français des relations internationales (Ifri).

Nwozor, A. (2010). A Delta of a Minefield: Oil Resource Conflict and the Politics of Amnesty in Nigeria. Conflict Trends, 1, 31-32.

Obasi, N. (2009). Yar'Adua Should Draw Up Roadmap to Delta Peace. International Crisis Group, Retrieved November 30, 2009, from http://www.crisisgroup.org/en/regions/africa/west-africa/nigeria/op-eds/obasi-yar-adua-should-draw-up-roa dmap-to-delta-peace.aspx bid

Obi, C. I. (2010). Oil Extraction, Dispossession, Resistance, and Conflict in Nigeria's Oil-Rich Niger Delta. Canadian Journal of Development Studies (Special Issue on: Rethinking Extractive Industry: Regulation, Dispossession, and Emerging Claims) XXX (1-2), 219-236.

Obi, C., \& Rustad, S. A. (2011). Conclusion: amnesty and post-amnesty peace, is the window of opportunity closing for the Niger Delta? In Obi, C. \& Rustad, S. A. (Eds.), Oil and Insurgency in the Niger Delta: Managing the complex politics of petro-violence. London/New York: Zed Books.

Ofehe, S. (2010). Features on Niger Delta Amnesty. Ex Ponto Magazine. Retrieved May 11, 2010, from $\mathrm{http}: / / \mathrm{www}$.expontomagazine.com/nl/reportages/2279-features-on-niger-delta-amnesty

Ogege, S. O. (2011). Amnesty Initiative and the Dilemma of Sustainable Development in the Niger Delta Region of Nigeria. Journal of Sustainable Development, 4(4), 249-258.

Oluwaniyi, O. O. (2011). Post-Amnesty Programme in the Niger Delta: Challenges and Prospects. Conflict Trends, $4,46-54$.

Omotola, S. (2007). From the OMPADEC to the NDDC: An Assessment of State Responses to Environmental Insecurity in the Niger Delta, Nigeria. Africa Today, 54(1), 73-89. http://dx.doi.org/10.2979/AFT.2007.54.1.72

Osaghae, E. E. (2008). Social Movements and Rights Claims: The Case of Action Groups in the Niger Delta of Nigeria. Voluntas, 19, 189-210. http://dx.doi.org/10.1007/s11266-008-9061-0

Osaghae, E., Ikelegbe, A., Olarinmoye, O., \& Okhonmina, S. (2011). Youth Militias, Self Determination and Resource Control Struggles in the Niger-delta Region of Nigeria. Dakar, Senegal: Council for the Development of Social Science Research in Africa (CODESTRIA). Retrieved from http://www.codesria.org/IMG/pdf/CDP_Nigeria2-2.pdf

Oshionebo, E. (2009). Regulating Transnational Corporations in Domestic and International Regimes: An African Case Study. Toronto, Buffalo \& London: University of Toronto Press.

Pro-Natura International. (2011). How to Transform the Lives of 1.6 Million People in Nigeria. Pro-Natura International Newsletter. June edition. Retrieved from http://www.pronatura.org/wp-content/uploads/2011/11/Akassa-Nigeria-Pro-Natura-2011-En.pdf

Report of the Technical Committee on the Niger Delta. (2008). Retrieved from http://www.mosop.org/Nigeria_Niger_Delta_Technical_Committee_Report_2008.pdf

Sachs, J. D. (2005). The End of Poverty: Economic Possibilities of Our Time. New York: Penguin Books.

Saro-Wiwa, K. (1998). Why I championed Ogoni Cause. In Olorode, O., Raji, W., Ogunye, J., \& Oladunjoye, T. (Eds.), Ken Saro-Wiwa and the Crises of the Nigerian State, Lagos: Committee for the Defence of Human Rights (CDHR) Publication.

Statoil. (2007). Akassa $\quad$ Model. $\quad$ Retrieved from http://www.statoil.com/en/environmentsociety/sustainability/2007/society/countrycases/nigeria/pages/akass amodel.aspx

Suberu, R. T. (1996). Ethnic Minority Conflicts and Governance in Nigeria. Ibadan: Spectrum Books Ltd.

Tar Sands Action. (2011). Ottawa Tar Sands Action Underway. Retrieved September 26, 2011, from http://www.tarsandsaction.org/ottawa-tar-sands-action-underway/ 
The News. (1993, May 17). pp.18-20.

Ukiwo, U. (2003). Politics, Ethno-Religious Conflicts and Democratic Consolidation in Nigeria. Journal of Modern African Studies, 41(1), 115-138. http://dx.doi.org/10.1017/S0022278X02004172

Ukiwo, U. (2011). The Nigerian State, Oil and the Niger Delta. In Obi, C. \& Rustad, S. A. (Eds.), Oil and Insurgency in the Niger Delta: Managing the complex politics of petro-violence. London/New York: Zed Books.

UNDP Human Development Report. (2011). Sustainability and Equity: A Better Future for All. Explanatory note on 2011 HDR composite indices Nigeria. Retrieved from http://hdrstats.undp.org/images/explanations/NGA.pdf

UNEP Report. (2011). Environmental Assessment of Ogoniland. Kenya: UNEP.

$\begin{array}{lllll}\text { Vanguard. } & \text { (2009). } & \text { Retrieved } & \text { June }\end{array}$ http://www.vanguardngr.com/2009/06/okah-freed-as-yaradua-signs-amnesty-deal/

Watts, M. (2008). Sweet and Sour. In Michael Watts (Ed), Curse of the Black Gold: 50 Years of Oil in the Niger Delta. New York: powerhouse Books.

\section{Notes}

Note 1. Suberu, R. T. (1996). Ethnic Minority Conflicts and Governance in Nigeria, Spectrum Books Ltd., Ibadan, pp. 35-47.

Note 2. This occurred in November 1990, the law enforcement agencies sacked Umuechem community killing about twenty persons, including a law enforcement officer, the community's traditional leader and two of his sons. See African Concord, 3 December 1990, pp. 23-27, quoted in Suberu, R. T. (1996) Ethnic Minority Conflicts and Governance in Nigeria, Op cit, p. 35.

Note 3. For example, the police opened fire on a peaceful protest against Shell contractors in the Ogoni village of Biara in April, 1993, leaving at least eleven people seriously injured and one person dead. See The News, 17 May 1993, pp. 18-20, quoted in Suberu, R.T. Ibid.

Note 4. This occurred in 1999 under President Olusegun Obasanjo when the State carried out a scorched earth action against Odi- a town in Bayelsa State in the Niger Delta in retaliation to the killing of law enforcement agents, who had been drafted to the area to quell riots. More than 2000 people were allegedly killed, many injured, several women raped, unquantifiable resources destroyed with several people displaced. Describing the situation, Senator Okadigbo, C. the then Senate President of Nigeria who visited the community a week after the gory incident stated that: 'the facts speak for themselves...there is no need for speech because there is nobody to speak to.' See Aghalino, S. O. (2009) 'The Olusegun Obasanjo Administration and the Niger Delta Question' 1999-2007, Stud Tribes Tribals, 7(1), 57-66.

Note 5. The soldiers bombarded the town of Odioma, in Bayelsa State on 19 February, 2005 allegedly pursuing militants. Not less than 17 people were killed, including an elderly woman and a two year old child, both burnt to death and several women raped. See S.O. Aghalino, Ibid.

Note 6. In May 2009, President Umaru Yar'Adua ordered a military operation in the Gbaramatu Kingdom, which covered Oporoza, Okerenkoko, Kunukunuma, Kurutie, Kokodiaghene, Ibafa among others, all in the Niger Delta region to apprehend some militants suspected to have murdered 12 members of Joint Task Force, including a Lt. Colonel on April 13 2009. This military operation which was more than a colossal massacre and genocide claimed more than 2,000 persons, mostly innocent aged men and women as well as children. This is aside from the lootings, raping, maiming and burning of these communities by the soldiers. See Adebayo, S. 'Niger Delta: We have lost over 2,000 persons- Gbaramatu Kingdom' Punch, 23 May, 2009 at http://archive.punchng.com/Articl.aspx?theartic=Art20090523643265

Note 7. Following the opposition by the Niger Delta leaders to the government bid to hosting the Niger Delta Peace Committee in 2008, the Niger Delta leaders suggested that what the 'Federal government should do is to set up a body to appraise the various reports that have been submitted on the way forward for the Niger Delta, from the Willink Commission of 1958 to 2007 and let the body come out with the things to be done or not done from the different reports, and then, the larger house like the stakeholders gathered, could be called to fine-tune and ratify the final report.' (AllAfrica, 1 July, 2009), quoted in Obi, C. and Rustad, S. A. (2011) 'Conclusion: amnesty and post-amnesty peace, is the window of opportunity closing for the Niger Delta?' In Obi, C., \& Rustad, S. A. (Eds.), 
Oil and Insurgency in the Niger Delta: Managing the complex politics of petro-violence (p. 201). Zed Books, London/New York.

Note 8. This theory, according to Draman stresses that sometimes people perceive themselves to be deprived relative to others and it is this that leads to inter-group hostility, rather than the actual relative status of the two groups, see Draman, R. Ibid. 